\title{
Meet the 2020 Fund for Latino Scholarship Recipients
}

\author{
JASMINE SCOTT | AMERICAN POLITICAL SCIENCE ASSOCIATION
}

T

he Fund for Latino Scholarship's primary goal is to encourage and support the recruitment, retention, and promotion of Latina/o political scientists (especially students and tenure track junior faculty); the secondary goal is to support research on Latino politics in the United States. Grants for the 2020 cycle were awarded to those individuals whose purposes most clearly match the goals of the fund, and whose proposals most persuasively demonstrate capacity for successful completion. Applications for the fund close annually each June.

Nicolas Albertoni is a PhD candidate in political science and international relations at the University of Southern California. His research broadly engages questions in international political economy and comparative politics with an emphasis on Latin America trade policy making and economic integration. His dissertation project, "The Risk of Trade Protectionism in an Era of Trade Interdependences and Economic Uncertainty," analyzes how states-

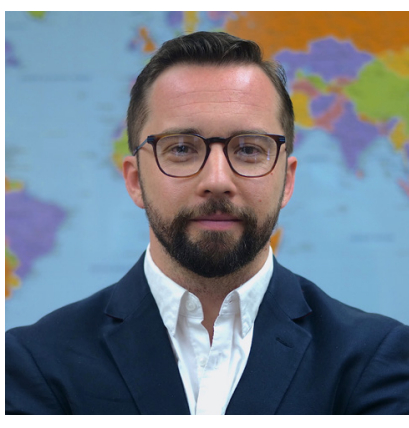
especially in the developing world-have been affected by and responded to rising protectionist trends that occurred in a context of high trade interdependence (through preferential trade agreements and global value chains) and economic uncertainty. His research project bridges academics and trade policy making and provides a roadmap for commercial policy reforms that will be essential for the successful revival of world markets post-COVID-19. He will use his award from the Fund for Latino Scholarship to fund research related to his dissertation.

Noemi Alexander is a gradvate of Claremont Graduate University where she received her $\mathrm{PhD}$ in political science with a subfield in race, ethnicity and politics. She is an assistant professor of political science and public administration at California Baptist University. Her recent dissertation research is on the political preferences of Latino-evangelicals in Southern California. Support from the Fund for Latino Scholarship will go toward enhancing her qualitative dissertation research with quantitative analysis. The funds from the scholarship will be used to conduct more interviews, distribute surveys, and purchase analytical software. Alexander enjoys presenting on topics of integration of faith, politics, and race; racial equity; racial reconciliation; and the strength of women in society.

Estefania Castañeda Pérez is PhD candidate in the Department of Political Science at the University of California, Los Angeles. Castañeda Pérez's doctoral dissertation research examines how enduring state violence at the Mexico-US border impacts the lives of transborder commuters. Her research is supported by the National Science Foundation and the Ford Foundation. The Fund for Latino Scholarship will support her qualitative data collection, in which she will con-

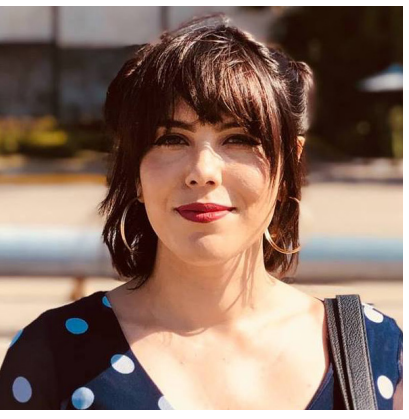
duct in-depth interviews with students, shoppers, and workers who cross through ports of entry along the CA, AZ, and TX borderlands.

Fernando Luiz Cavalcante is a postdoctoral researcher at the Department of Applied Linguistics of the State University of Campinas (UNICAMP), Brazil. Cavalcante works with visual data to get insights with Natural Language Processing (NLP). He is the creator of QualiChat, a computational methodology to be available in Python and $R$ for analysis of interaction frames on WhatsApp groups. Cavalcante researches the mediatization of politics in Latin America focus-

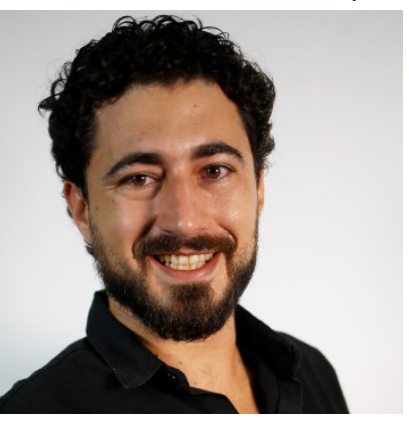
ing on the links of interaction in mediatized groups and is a media ethnographer specializing in human-computer interaction by framing linguistic corpora overhead in quantitative reports. $\mathrm{He}$ is also a senior qualitative researcher at Ernest Manheim Lab leading usability tests, focus groups, in-depth interviews, eye tracking by driving, and analyzing qualitative data. Since 
2014, Cavalcante has worked as an adjunct professor at the Department of Communication at UNI7, Fortaleza, Brazil. He is also the ZeMKI Visiting Research Fellow 2020 at the University of Bremen (Germany).

Alejandro Contreras is a PhD student at Brown University studying American politics. He holds a master's degree in public administration from San Diego State University as well as a BS in Criminal Justice and BA in Spanish. His current research interests encompass issues of race and immigration in federal, state, and local policy. The support from the Fund for Latino Scholarship will assist in conducting research in San Diego, California on the relationship

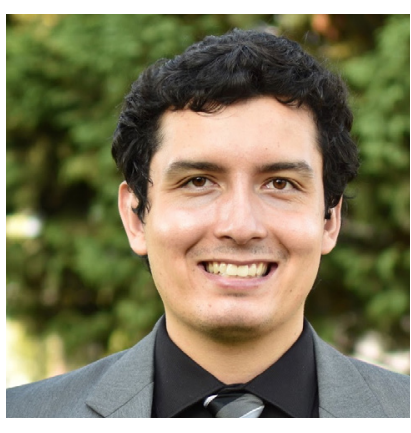
between deportation and housing insecurity/homelessness among Latino families. Particularly, the funds will be used to compensate interview and survey participants. Alejandro hopes his research can be used to impact federal, state, and local policy on immigration and social welfare.

Kennia L. Coronado is a PhD student in the Department of Political Science at the University of Wisconsin-Madison. Her research interests lie at the intersection of Latinx political behavior, identity, political communication, and representation. Her dissertation will explore how Latinxs are mobilized to participate in US presidential elections-even when they are not eligible to vote-and how these processes matter for their understandings of themselves as political beings. She will use the financial support from the Fund

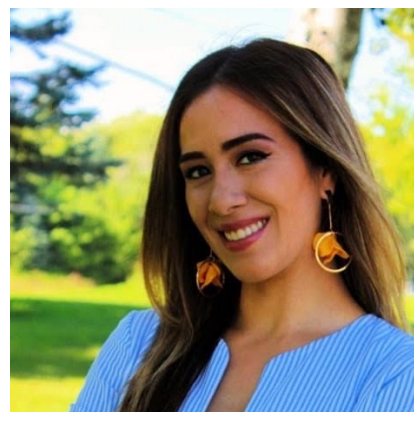
for Latino Scholarship towards data collection efforts for her dissertation. Kennia is an affiliate of the Elections Research Center (ERC) at UW-Madison, a recipient of the 2017 APSA Minority Fellowship, a 2015 APSA Bunche Fellow, and received her BA in political science and Latin American, Caribbean, and US Latinx studies at the University of Wisconsin-Milwaukee.

Luzmarina Garcia is a PhD student at the University of Illinois at Urbana-Champaign. Her research interests are at the intersection of judicial and identity politics. Her dissertation project examines whether the gender bias that has been found in certain types of courts reflects a fundamental behavior that can be found across courts and in the general population. She considers institutional factors such as the breadth of case types, case law, and court function to reveal a more accurate

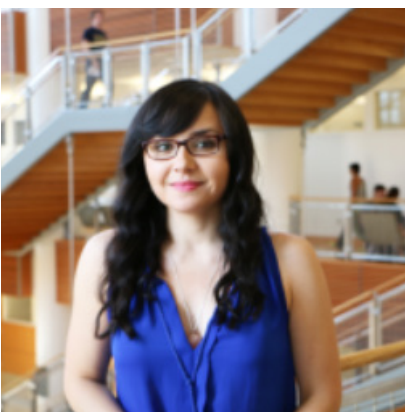
depiction of the role of gender in judicial decision making, ex- tending the literature to administrative benches, such as immigration and tax courts. Garcia is a Schroeder fellow at the Cline Center for Advanced Social Science Research, and a recipient of the APSA Minority Fellowship and UIUC Graduate College Fellowship. She holds a master's degree in political science from UIUC and a bachelor's degree in political science and communication studies from the University of Texas at El Paso. The Fund for Latino Scholarship will allow her to extend web-scraping collection of administrative-court data.

Julia Marin Hellwege is an assistant professor at the University of South Dakota in the Department of Political Science. She is also affiliated with the Women, Gender, and Sexuality Studies program and serves as the APSA Latino Caucus Webmaster. She earned her PhD from the University of New Mexico in 2016. Her primary research concentration lies in the interaction between political institutions and identity, particularly as related to the political representation of women and other marginalized identities, includ-

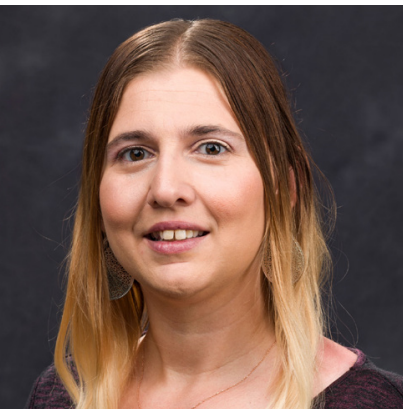
ing race and ethnicity. She has published in American Politics Research, Journal of Interpersonal Violence, Social Science Quarterly, Journal of Political Science Education, Policing: an International Journal, and Politics, Groups, and Identities. Her research has been featured in the Monkey Cage, the LegBranch blog, and the LSE USCentre blog; she has also published short pieces in Mischiefs of Faction. Dr. Hellwege intends to use the funds to hire a research assistant to push forward her book-length project on how identity and legislative proportions affect surrogate representation among state legislators.

Jennifer Martinez is a PhD candidate in the Public Affairs and Policy program at Portland State University. Her dissertation questions how remittances impact civic participation in receiving communities. Notably, she focuses on how narratives about sacrifice circling the transfers may veil governing bodies from being responsive and held to account while perpetuating exploitative labor arrangements that force communities to disperse in search of a livelihood. Her broader research interests focus on political par-

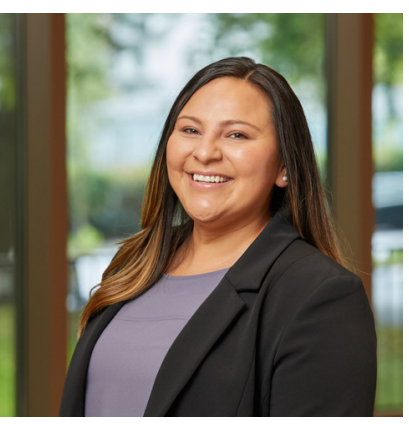
ticipation and intersect with her advocacy work and public finance background. She plans to use the APSA Fund for Latino Scholarship award to start her data collection efforts in the field.

Maricruz Osorio is a PhD student at the University of California, Riverside. Broadly, her work looks at the political engagement and behavior of marginalized groups, with an emphasis on women and immigrants. She has published in this work academically and has contributed to other forms of publicly available 
scholarship, including policy reports, blogs, and encyclopedia entries. Her dissertation investigates the role of gender in forming risk assessments, whether risks are perceived to be risks themselves or risks are believed to be risks to their community at large. She analyzes how those risk assessments contribute to the political participation, in all

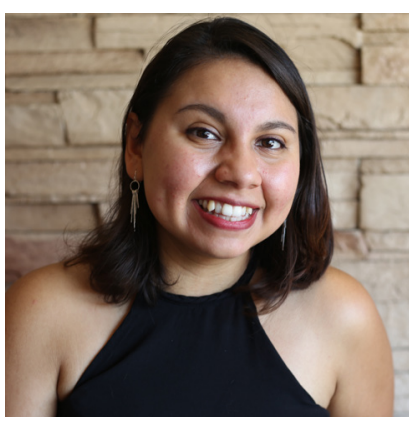
its different forms, of marginalized immigrant communities. Her dissertation looks at how agency might manifest differently by citizenship status and hopes to add to our understanding of political participation. Outside of academic work, Maricruz is a founding member of People of Color Also Know Stuff. She has been an invited speaker on issues of equity, diversity, and inclusion in academia.

Carlos Rivera Garcia is currently postdoctoral scholar at the University of California, Berkeley. Carlos received his $\mathrm{PhD}$ in psychology from the University of Essex. His research interests lie in the intersection of political psychology and political behaviour. $\mathrm{He}$ is particularly interested in understanding the psychological processes by which the Latinx community develop and adjust their political loyalties and how their personality traits, cognitive styles, and emotions influence their political behaviors and political participation or lack thereof le.g.

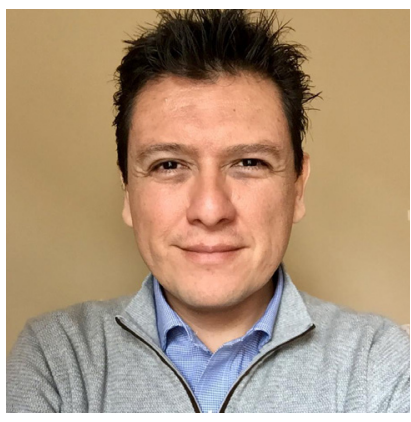

voting, canvassing, volunteering, donating money, displaying signs, participating in local organisations, and violent forms of protest). The APSA Fund for Latino Scholarship-together with an institutional grant-will help Carlos to complete the data collection stage of his study on the psychological underpinnings of civic engagement and political participation among the Latino population in the US. His work will advance the understanding of the various forms of political participation among minority groups. Carlos aims to present the results of his research during APSA's Annual Meeting \& Exhibition.

Angel Saavedra Cisneros is an assistant professor of political science at St. Norbert College in Wisconsin. He received his PhD from Stony Brook University and focuses on political psychology and minority politics. His 2017 book Latino Identity and Political Attitudes: Why Are Latinos Not Republican? received the APSA REP organized section 2017 Best Book in Race and Political Behavior Award. His current research focuses on identity, social cognition, and the role of identity complexity on political behaviors. This fall

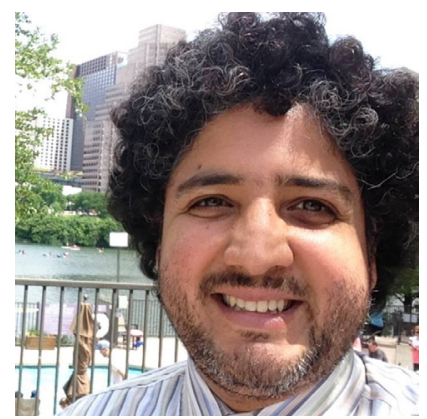
he will launch the St. Norbert

College Political Identities lab where he will work with undergraduates to research questions of multiple identities and rural multiracial communities. He also applies measurement and comparative methodologies to the study of political psychology among sociodemographic groups in the United States. His interests in immigration extend to the study of Latin American views on migrants from neighboring Latin American countries, in particular the cases of México and Colombia. The Fund for Latino Scholarship award will be used to purchase a larger, more diverse, and representative sample of Latinx respondents for a pre-registered experiment on identity, emotions, and policies for the 2020 Election.

\section{Do you want to keep receiving Political Science Today?}

\section{Update your journal delivery preferences} through the User Home page on the APSA website at www.apsanet.org/user-home. Members who do not opt in will stop receiving Political Science Today in print. Digital editions of Political Science Today are available online at: www.apsanet.org/today
POLITICAL SCIENCE

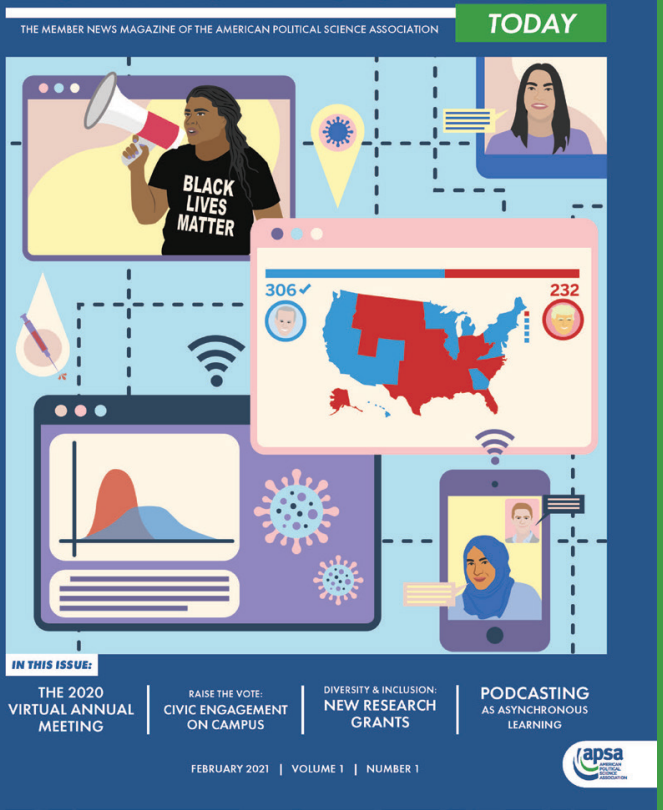

